\title{
INCREASING THE PRODUCTION OF RUBBER PLANTATIONS AND INVESTMENT OPTIONS OF RUBBER FARMERS IN JAMBI PROVINCE
}

\author{
Mara Armen*, Amir Amri, Napitupulu Dompak, Zamzami \\ Independent Researchers, Indonesia \\ *E-mail: armenmara705@yahoo.com
}

\begin{abstract}
The objective of the research is to analyze the increase of rubber plantation production in Jambi Province, the factors affecting production, and the investment choice for farmers in increasing production. To know the factors that influence the production of smallholder rubber plantation in Jambi Province used multiple linear regression analysis. Furthermore, to explain the investment options for rubber farmers there are two options, namely intensification or extensification. The choice of intensification will lead to increased land productivity. Extensification options do not lead to increased productivity because there is no technological change, especially the use of modern inputs. The result of research shows that productivity of rubber plantation in Jambi Province which generally use traditional method is still low, that is equal to $865 \mathrm{~kg} / \mathrm{ha} / \mathrm{year}$; the development of rubber plantation production in Jambi Province is quite rapid, at $2.65 \%$ per year (however, the increase in productivity of smallholder rubber plantations is slow, at $0.238 \%$ per year); the factor of the area of smallholder rubber plantation and the number of rainy days has a significant effect on rubber plantation production. This study reveals that farmers are more likely to choose extensification that can be done traditionally with lower risk levels, while intensification options should be done in a modern way, greater cost, and a greater risk of failure.
\end{abstract}

\section{KEY WORDS}

Extensification, intensification, production, productivity.

Jambi Province has economic potential in agriculture, where the agricultural sector contributes as much as $29.83 \%$ in Gross Domestic Regonal Product (GDRP). From the agriculture sector, the plantation sub-sector is the largest in terms of $16.31 \%$ (BPS, 2015). There are 6 (six) commodities that have been established as leading commodities in Jambi Province, namely rubber, palm oil, coconut, cinnamon, coffee, and areca nut. Judging from the number of farmers and plant area, rubber commodity topped the area with 664,739 ha (Budidaya, 2015).

Rubber plantations (Hevea braziliensis) in Jambi province are still traditionally cultivated, namely mixed cropping systems. On the same plot of rubber planted in conjunction with other crops and grow jostling with other plants. Therefore, the rubber plant has advantages, which are environmentally friendly and include the category of forestry crops as well as functioning as forest rehabilitation. Rubber plants is one type of plant that has a high tolerance to soil fertility (Falah et all, 2011).

Rubber plantations have the potential to grow and produce in 7 (seven) districts (of 11 districts /cities) in Jambi Province. Potential districts are Sarolangun, Merangin, Bungo, Tebo, Batanghari, Muaro Jambi and Tanjung Jabung Barat. Therefore, given the vastness of rubber plantations, the large number of farmers who depend on the plantation business, and the nature of their hospitality to the environment, the rubber plantation is considered very potential to be developed in addition to other plantation crops (BPS,2015). Rubber plantation has the potential to become "the prime mover sector" (base sector) in the regional economy in Jambi Province (Sorenson, 2007.

The productivity of rubber plantation in Jambi Province is relatively low. In 2014, land productivity is $960 \mathrm{~kg} / \mathrm{ha} / \mathrm{year}$ (Jambi Provincial Plantation Office, 2015) while the productivity of rubber plantation in South Sumatera Province (neighboring province) is $1.440 \mathrm{~kg} / \mathrm{ha} / \mathrm{year}$ (Agustina,2015). The productivity of rubber plantations in Malaysia is $1,100 \mathrm{~kg} / \mathrm{ha} / \mathrm{year}$, India 
$1,334 \mathrm{~kg} / \mathrm{ha} /$ year, Vietnam 1,358 kg/ha /year and Thailand 1,600 kg/ha/year (Boerhenhdy, 2013). To improve the productivity of the land needs improvement in technology or quality of the garden. Research on rubber plantations intensively cultivated in Indonesia, using 100 series rubber clones or 200 rubber plantations can produce 2,141 to $2,734 \mathrm{~kg} / \mathrm{ha} / \mathrm{year}$ (Daslim, 2014).

The phenomenon of low productivity of rubber plantations in Jambi Province cannot be fully explained by the classical economic theory approach, where the use of input (capital, labor, and technology) will increase production to the maximum point, $y=f(c, l, t)$ (Miller, 1997). Several studies conducted in Southeast Asia have found that productivity is influenced by other aspects outside the economic aspect. Among the social aspects that give rise to economic "dualism" (Booke, 1983), the cultural aspects that give rise to "agricultural involution" (Geertz, 1976), the moral-economic aspect that causes farmers to be reluctant to accept technolgy (Scott 1981), and the institutional and labor supply aspects (Hayami et al (1987).

Increased production of rubber plantations can be done in two ways, namely through intensification (improvement of cultivation techniques) and extensification (area expansion). Intensification is done with technological improvements so that land productivity increases. The low productivity of rubber plantations in Jambi Province shows that farmers are still reluctant to intensify. Rubber plantation replanting program as one of the intensification program through technological improvement with the aim of increasing land productivity has been done since 2006 but did not give satisfactory result.

This study aims to: 1) Analyze the factors that influence production, i.e. the area of land, the number of rainy days, the number of farmers, the price of rubber, the length of the asphalt road, and the capacity of the industry. 2) Analyze the increase of land productivity. 3) Analyze farmers' choice to extend or intensify.

\section{METHODS OF RESEARCH}

This research is a "survey" methode (Yunus, 2010) taking place in Jambi Province, where rubber is the main product besides other plantation products. This research was conducted in 2016, ie from April to November 2016. Using secondary data existed in related institutions, including BPS-Statidtic Of Jambi Province (BPS), Plantation Office (Dinas Pekerkebunan), Public Work Office (Dinas Pekerjaan Umum), and Tade and Industry Offices (Dinas Perindustrian dan Perdagangan). This study uses secondary data which collected data from 2001 until 2015.

The main variables observed were rubber production and rubber land productivity. Furthermore, rubber production is related to rubber plantation area, number of rainy days, number of rubber farmers, rubber price, length of asphalt road, and rubber factory capacity to rubber price in Jambi Province. Further data collected by data tabulation and statistical analysis econometric with model of Multiple Linear Regression. Trend analysis and descriptive analysis. The mathematical relationship between the rubber plantation production variables and the factors that influence them can be written as the Multiple Regression Model as follows (Pindyck 1998).

$$
Y_{1 i}=\beta_{0}+\beta_{1} X_{1 i}+\beta_{2} X_{2 i}+\beta_{3} X_{3 i}+\beta_{4} X_{4 i}+\beta_{5} X_{5 i}+\beta_{6} X_{6 i}+e
$$

Where: $Y_{1 i}=$ Production of rubber plantations in year i (Ton); $B_{0}=$ constants; $B_{1}, \beta_{2}, \beta_{3}, \beta_{4}, \beta_{5}$, $\beta_{6}=$ Elasticity of the above variable $E=$ error; $X_{1 i}=$ Area of rubber plantation produces in Jambi Province in year $\mathrm{i}$ (ha); $\mathrm{X}_{2 \mathrm{i}}=$ Number of rainy days in Jambi Province in year $\mathrm{i}$ (days/year); $X_{3 i}=$ Number of rubber farmers in Jambi Province in year i (mm3/year); $\mathrm{X}_{4 \mathrm{i}}=$ Rubber price in Province in year $\mathrm{i}\left(\$ /\right.$ Kwintal); $\mathrm{X}_{5 \mathrm{i}}=$ Length of asphalt road in Jambi Province in year $\mathrm{i}(\mathrm{Km}) ; \mathrm{X}_{6 \mathrm{i}}=$ Capacity of rubber factory in Jambi Province in year $\mathrm{i}$ (Ton / Year) 
This research, analysis was use data processing program by the Application Program Eviews (Nachrowi, 2006). With this application program all the steps required in testing the econometric model can be done so that the final result can be trusted to draw conclusions.

\section{RESULTS AND DISCUSSION}

\section{The factors affect Rubber Plantation Production}

The development of rubber plantation production is a description of the progress and movement of development of a region, especially in the field of rubber plantation. The faster the development of rubber plantation production the more visible progress of development in the area. In general, the development of rubber plantation production is determined by the first, the expansion of the so-called extensification area and secondly, the addition of inputs called intensification. There are several factors suspected to affect rubber plantation production, i.e. land area, number of rainy days, number of rubber farmers, rubber price, length of asphalt road, and factory capacity.

Table 1 - Rubber plantation production and influencing factors in Jambi Province from 2001-2015

\begin{tabular}{ccccccccc}
\hline Num & Years & $\begin{array}{c}\text { Production } \\
\text { (ton) }\end{array}$ & $\begin{array}{c}\text { Land } \\
\text { area } \\
\text { (ha) }\end{array}$ & $\begin{array}{c}\text { Number } \\
\text { of rainy days } \\
\text { (days/month) }\end{array}$ & $\begin{array}{c}\text { Number } \\
\text { of farmer } \\
\text { (mans) }\end{array}$ & $\begin{array}{c}\text { Rubber } \\
\text { price SIR 20 } \\
(\$ / k w)\end{array}$ & $\begin{array}{c}\text { Length of } \\
\text { asphalt } \\
\text { road }(\mathrm{km})\end{array}$ & $\begin{array}{c}\text { Factory } \\
\text { capacity } \\
\text { (ton/month) }\end{array}$ \\
\hline 1 & 2001 & 239,330 & 326,201 & 14.80 & 194,391 & $488,454.00$ & $2,512.48$ & 243,000 \\
\hline 2 & 2002 & 239,625 & 329,471 & 15.01 & 190,113 & $572,286.00$ & $10,164.99$ & 43,000 \\
\hline 3 & 2003 & 241,328 & 335,900 & 13.50 & 188,344 & $697,600.00$ & $2,896.80$ & 289,200 \\
\hline 4 & 2004 & 236,317 & 325,076 & 14.20 & 216,724 & $114,540.00$ & $2,387.08$ & 364,500 \\
\hline 5 & 2005 & 247,568 & 335,094 & 13.10 & 226,908 & $124,500.00$ & $2,387.08$ & 288,300 \\
\hline 6 & 2006 & 266,263 & 337,028 & 8.60 & 228,576 & $168,633.00$ & $2,387.07$ & 324,300 \\
\hline 7 & 2007 & 264,674 & 334,499 & 17.50 & 235,888 & $197,333.00$ & $2,387.07$ & 324,300 \\
\hline 8 & 2008 & 271,752 & 337,417 & 15.80 & 246,380 & $24,821.00$ & $2,387.07$ & 339,300 \\
\hline 9 & 2009 & 280,620 & 338,296 & 14.80 & 251,184 & 155.28 & $2,307.08$ & 312,800 \\
\hline 10 & 2010 & 288,981 & 342,261 & 18.40 & 251,403 & 294.83 & $2,417.01$ & 312,800 \\
\hline 11 & 2011 & 298,786 & 342,851 & 15.50 & 249,978 & 383.08 & $2,417.01$ & 387,300 \\
\hline 12 & 2012 & 322,044 & 349,184 & 13.80 & 252,505 & 313.33 & $2,441.41$ & 360,800 \\
\hline 13 & 2013 & 325,991 & 354,098 & 17.70 & 254,134 & 258.02 & $2,441.41$ & 367,000 \\
\hline 14 & 2014 & 342,998 & 357,138 & 15.80 & 255,663 & 130.85 & $2,441.41$ & 472,200 \\
\hline 15 & $2015^{*}$ & 350,457 & 359,128 & 14.70 & 254,813 & 230.00 & $2,441.41$ & 472,200 \\
\hline
\end{tabular}

Source: Processed from BPS, 2015 and the others.

After analysis with multiple regression model, by using application program "eviews" with stages as appropriate, multicollinearity test, autocorrelation test, heteroscedasticity test then obtained the result or model as follows:

$$
Y=-812159,8+733,5238 X 1-0,063014 \times 2-0,033062 X 3+0,495689 \times 4+3,239800 \times 5+0,396676 \times 6+e
$$

From the regression equation model can be explained that the result of $\mathrm{R}$ squared of 0.963942 obtained the understanding that the production function is able to explain the independent variables, namely the rubber plantation area, the number of rainy days, the number of rubber farmers, the price of rubber, the length of the asphalt road, and the factory capacity affect the dependent variable together, ie rubber plantation production with $96 \%$ confidence level and only $4 \%$ influenced by other variables.

Furthermore, the results of analysis through partial testing or individually obtained the result that the factor of rubber plantation area and the number of rainy days have significant effect on rubber plantation production. Other variables such as number of rubber farmers, rubber price, length of asphalt road, and factory capacity affect rubbers plantation insignificantly in Jambi Province.

Development of Production and Productivity of Rubber Plantation in Jambi Province. Production and productivity of rubber plantations is one indicator of the progress of rubber plantation development in Jambi Province. Increased production will show an increase in 
farmers' income. Therefore, farmers will try to increase production in order to increase their income.

Productivity describes technological advances, whether biotechnology, chemical technology, or mechanization technology. The higher the productivity of the rubber plantation the more advanced the plantation and the more prosperous the farmers. Farmers' income depends on the total production they receive. Production can be increased by increasing the area of land (extensification) or increasing land productivity (intensification). The development of production, productivity, and extent of rubber plantations in the Province from 2001-2015 can be explained in Table 1.

Table 2 - The development of rubber plantation production and productivity in Jambi Province, 2001-2015

\begin{tabular}{|c|c|c|c|c|c|c|c|}
\hline Num & Years & Production (kg) & Growth (\%) & Land area (ha) & Growth (\%) & $\begin{array}{l}\text { Produktivitas } \\
\text { (ton/ha) }\end{array}$ & Growth (ton) \\
\hline 1 & 2001 & 239,330 & - & 326,201 & - & 0.7337 & \\
\hline 2 & 2002 & 239,625 & 0.12 & 329,471 & 0.99 & 0.7273 & 0 \\
\hline 3 & 2003 & 241,328 & 0.71 & 335,900 & 1.91 & 0.7185 & $(0.01)$ \\
\hline 4 & 2004 & 236,317 & $(2.12)$ & 325,076 & (3.33) & 0.7270 & 0.01 \\
\hline 5 & 2005 & 247,568 & 4.54 & 335,094 & 2.99 & 0.7388 & 0.01 \\
\hline 6 & 2006 & 266,263 & 7.02 & 337,028 & 0.57 & 0.7900 & 0.05 \\
\hline 7 & 2007 & 264,674 & $(0.60)$ & 334,499 & $(0.76)$ & 0.7913 & 0 \\
\hline 8 & 2008 & 271,752 & 2.60 & 337,417 & 0.86 & 0.8054 & 0.02 \\
\hline 9 & 2009 & 280,620 & 3.16 & 338,296 & 0.26 & 0.8295 & 0.02 \\
\hline 10 & 2010 & 288,981 & 2.89 & 342,261 & 1.16 & 0.8443 & 0.01 \\
\hline 11 & 2011 & 298,786 & 3.28 & 342,851 & 0.17 & 0.8715 & 0.03 \\
\hline 12 & 2012 & 322,044 & 7.22 & 349,184 & 1.81 & 0.9223 & 0.05 \\
\hline 13 & 2013 & 325,991 & 1.21 & 354,098 & 1.39 & 0.9206 & 0 \\
\hline 14 & 2014 & 342,998 & 4.96 & 357,138 & 0.85 & 0.9604 & 0.04 \\
\hline \multirow[t]{2}{*}{15} & 2015 & 350,457 & 2.13 & 359,128 & 0.55 & 0.9759 & 0.02 \\
\hline & Average & - & 2.65 & - & 0.67 & - & 0.02 \\
\hline
\end{tabular}

Source: Processed from BPS, 2015. Jambi in Figures 2001-2015.

Table 1 can be explained that the production of rubber plantations in Jambi Province from 2001 to 2015 tends to increase every year, except in 2004 and in 2007 there was a decline. The average rubber plantation production increased by 7,938 tons $(2.65 \%)$ per year and the land area increased by 2,352 ha per year $(0.67 \%)$ while the productivity only increased on average by 0.02 tons per ha or by $20 \mathrm{~kg} / \mathrm{ha} / \mathrm{year}$. This illustrates that the increase in productivity is very slow and difficult to reach the ideal number as proposed Daslim (2014) that is equal to $2,734 \mathrm{~kg} / \mathrm{ha} /$ year.

Extensification and Intensification Options. A farmer and his family in Jambi Province can live well if they have a land area of at least 2 ha. If a farmer and family owns less than 2 hectares then he will endeavor to expand his plantation land with available land. To find out how much land owned by farmers and their families in Jambi Province can be known as follows. The total area of agricultural land in Jambi Province as described in table 4 below is $4,451,861$ ha, consisting of agricultural land of 4,220,199 ha and large plantation area of 231,662 ha. The number of farmers is 254,813 people (see table 3 ). According to the statistical data every farmer has a land area of $16.56 \mathrm{ha}$. This area is enough for the welfare of farmers and their families. However, the facts on the ground are less encouraging because there has been considerable imbalance in land ownership. Many farmers own a farm area of one hundred hectares and even a thousand ha. Conversely many farmers who have no land at all. In general it can be explained that farmers in Jambi Province only have land less than 2 ha.

To meet the farmers' need for land in Jambi Province, a farmer will expand the area. From a farmer's point of view (generally low-educated) that the land for agricultural land cultivation is still available, including in the form of shrubs, old rubber gardens, even forests they consider to be gardens. This has led to a large number of land disputes between farmers and other farmers, between farmers and urban dwellers with land in the village, and 
even disputes between farmers and the government who consider farmers to have planted gardens in forest areas. The description of land cover in Jambi Province in 2014 can be seen in table 4.

Table 3 - The development of area, production, productivity and farmers in 2014

\begin{tabular}{|c|c|c|c|c|c|c|c|}
\hline \multirow{2}{*}{ Year } & \multicolumn{4}{|c|}{ Area (Ha) } & \multirow{2}{*}{$\begin{array}{l}\text { Production } \\
\text { (Ton) }\end{array}$} & \multirow{2}{*}{$\begin{array}{c}\text { Productivity } \\
(\mathrm{Kg} / \mathrm{Ha})\end{array}$} & \multirow{2}{*}{$\begin{array}{c}\text { Farmers } \\
(\mathrm{HH})\end{array}$} \\
\hline & Immature & Mature & Damaged & Total & & & \\
\hline 2004 & 89,730 & 267,706 & 7,868 & 365,304 & 795,848 & 2,973 & 216,724 \\
\hline 2005 & 105,113 & 292,314 & 6,040 & 403,467 & 936,595 & 3,204 & 226,908 \\
\hline 2006 & 107,231 & 308,629 & 7,028 & 422,888 & $1,018,768$ & 3,301 & 228,576 \\
\hline 2007 & 102,106 & 338,844 & 7,949 & 448,899 & $1,150,355$ & 3,395 & 235,888 \\
\hline 2008 & 114,778 & 363,869 & 5,490 & 484,137 & $1,203,433$ & 3,307 & 246,380 \\
\hline 2009 & 113,954 & 371,808 & 3,622 & 489,384 & $1,265,789$ & 3,404 & 251,184 \\
\hline 2010 & 107,022 & 402,221 & 4,716 & 513,959 & $1,392,293$ & 3,462 & 251,403 \\
\hline 2011 & 110,259 & 417,304 & 4,730 & 532,293 & $1,426,081$ & 3,417 & 249,978 \\
\hline 2012 & 150,998 & 433,405 & 4,937 & 589,340 & $1,472,852$ & 3,398 & 217,542 \\
\hline 2013 & 143,172 & 444,588 & 5,673 & 593,433 & $1,555,697$ & 3,499 & 254,813 \\
\hline 2014 & 125,655 & 519,710 & 17,481 & 662,846 & $1,571,535$ & 3,024 & 255,932 \\
\hline
\end{tabular}

Source: Plantation Office of Jambi Province, 2015. Plantation Statistics 2015.

Table 4 - Total land cover in Jambi Province in 2013

\begin{tabular}{|c|c|c|c|}
\hline No & Region & Area $(\mathrm{Ha})$ & $\%$ \\
\hline A & Kawasan Lindung & & \\
\hline 1 & Hutan Lindung & 191.130 & 3,56 \\
\hline \multirow[t]{5}{*}{2} & Kawasan suaka alam, pelestarian alam & 676.120 & 12,61 \\
\hline & a. Cagar alam & 30.400 & 0,57 \\
\hline & b. Taman Nasional & 608.630 & 11,35 \\
\hline & c.Taman Hutan Raya & 36.660 & 0,68 \\
\hline & d.Taman Wisata Alam & 430 & 0,01 \\
\hline $\mathrm{B}$ & Kawasan Budidaya & & \\
\hline \multirow[t]{3}{*}{1} & Kawasan Pertanian & 4.451 .861 & 83,02 \\
\hline & a. Pertanian lahan basah & 684.060 & 12,76 \\
\hline & b.Pertanian lahan kering/tegalan/kebun campur & 3.767 .801 & 70,26 \\
\hline \multirow[t]{2}{*}{2} & Kawasan Pemukiman & 43.631 & 0,81 \\
\hline & Total & 5.362 .742 & 100,00 \\
\hline
\end{tabular}

The development of rubber plantation production in Jambi Province between 2001 and 2015 was quite rapid, with production increasing by $2,65 \%$ per year, Increased productivity of land runs slow, i.e. by 0,238 tons/ha/year (lihat Tabel 2). This explains that farmers are more likely to choose extensification than intensification, Intensification options will require modern business management, greater maintenance costs, and a greater risk of failure, The choice of extensification is done because of the social, cultural, moral, and labor aspects of the family as found by experts from the neoclassical group (Booke, 1983, Geertz, 1976, Scott, 1981, Hayami et all, 987) and Allowing farmers to cultivate with traditional management, at lower costs, and lower risk levels.

\section{CONCLUSION AND RECOMMENDATIONS}

The results showed that the regression model used in data analysis is good enough so that it can explain the influence of independent variables of $96 \%$, It can be explained also that the factor of rubber plantation area, the number of rainy days has a significant influence on rubber plantation production, while the variable of the number of rubber farmers, the rubber price, the length of the asphalt road, the factory capacity has no significant effect on rubber plantation production in Jambi Province.

The development of rubber plantation production in Jambi Province is quite rapid, that in 2001 the amount of production was 239,330 tons and in 2015 rubber plantation production increased to 350,457 tons, The growth rate is also quite convincing, ie an average of $2,65 \%$ per year. 
The results also reveal that farmers are more likely to choose extensification than intensification because traditional extensification options can be done traditionally, lower costs, and lower risk levels, Instead the intensification option should be done in a modern way, greater cost, and greater risk of failure.

It is suggested to be able to do further research, that is by using data of each regency which is Jambi Province, Using more and more extensive data, it is expected that the regression model obtained will be better and more reliable to determine future rubber plantation development policy.

\section{REFERENCES}

1. Agustina, D,S, Syarifa, L,F, Nancy, C, Rosyid, M,J, 2015. Analysis of rubber intercropping system in Probumulih City, South Sumatera Province. Indonesian Journal of NaturalRubber Research, Number 2 Volume 33 Year 2015, page 157-163. Rubber Research Institute. Palembang, Indonesia.

2. Boerhendhy,I, 2013. Management and technology of rubber cultivation. Seminar paper for technical meeting of Jambi plantation director general. Jambi.

3. Booke, J, H, 1953, Economics and economi Policy of dual societies.

4. BPS, 2015. Jambi in figures, The Central Bureau of Statistics and Bappeda of Jambi Province. Jambi.

5. Budidaya, 2015. Direction of plantation development in Jambi Province. Paper in Jambi Province plantation technical meeting, Jambi, March 26, 2015. Disbun Jambi Province. Jambi.

6. Daslim, A, 2014. Productivity of IRR100 and IRR 200 rubber clones on various agroclimates and tapping systems, Warta Perkaretan, Number 1 Volume 33 of 2014, pages 11-18, Rubber Research Center PT, Riset Perkebunan Nusantara, Jakarta.

7. Falah, $\mathrm{F}$ and Adinugroho,W,C, 2011, Aspect of Selection of Type in Rehabilitation of ExPeatland Project (PLG) Project in Kapuas Regency, Central Kalimantan, Partner Journal of Plantation Forest, Vol,6 No,2, August 2011,73-85,Bogor.

8. Geertz, C, 1983, Agricultural Involution, The process of ecological change in Indonesia, Bhratara by Aksara, Jakarta.

9. Hayami, Y and Kikuchi, M, 1987, Village economic dilemma, an economic approach to institutional change in Asia, Yayasan Obar Indonesia, Jakarta,

10. Jambi Provincial Plantation Office, 2015, Statistics of plantation of Jambi Province, Disbun Jambi Province, Jambi.

11. Miller, R, L, 1997, Economics today, Ninth edition, Addison-Wesley, New York.

12. Nachrowi $D$, and Usman, $H, 2006$, A popular and practical approach to econometrics for economic and financial analysis, Lembaga Penerbit FEUI, Jakarta.

13. Pindyck R, S and Rubinfeld, D, L, 1998, Econometric models and economec forcasts, Irwin McGraw-Hill, New York.

14. Regional Development Planning Board of Jambi Province, 2013. Regional Regulation of Jambi Province Number 10 year 2013 on Spatial Planning Jambi Province 2013-2033.

15. Regional Development Planning Board of Jambi Province, 2013. Specially Profil of Jambi Province for Spatial Planning Jambi Province 2013-2033.

16. Scott, C, J, 1981, Morale of peasant economy, upheaval and subsistence in Southeast Asia, LP3ES, Jakarta.

17. Sorenson,D,J, 2007, Assessing economicase relationships in South Dakota, The Journal of Regional Anylysis and Policy, MCRSA Presidential Symposium, JRAP 37(2):hal: 165182, Dakota Selatan.

18. Yunus, H,S, 2010, Research methodology of the area of komtemporer, Student Library, Yogyakarta. 